\title{
Contaminant of Heavy Metals in Groundwater \& its Toxic Effects on Human Health \& Environment
}

\author{
Mahipal Singh Sankhla* and Rajeev Kumar \\ Division of Forensic Science, Galgotias University, India
}

Submission: April 08, 2019; Published: April 23, 2019

*Corresponding author: Mahipal Singh Sankhla, Research Scholar, Division of Forensic Science, Galgotias University, Greater Noida, India

\begin{abstract}
Heavy metal is present in the various state on industrial waste water, natural water as a part of a natural water heavy metal are present in the ground water. The water is drinking of highly polluted and chronic effect on people are genetic disorders, nerutoxicological disorder and carcinogenicity. Toxic heavy metals are regularly discharge to the aquatic environment in India as a prompt development of Industry. The major issue to the time ground water are contaminated through heavy metal. Water is the dynamic source, essential for all aspects of human and ecosystem for existence and health. The levels of heavy metals contaminations in water like, $\mathrm{Pb}, \mathrm{Zn}, \mathrm{As}, \mathrm{Cr}$, $\mathrm{Ni}$ etc. in several water resources as groundwater, surface water, tap water etc. The review study provides heavy metal concentration in groundwater and to give recommendations to prevent the health risks against intake.
\end{abstract}

Keywords: Heavy Metals; Toxic; Effects; Groundwater; Humans

\section{Introduction}

Water is the most fundamentals that requirement of human, plant and animal life [1] and it is commonly found from two major sources natural; Fresh surface water, lakes, rivers, and ground water. Ground water are found in well water and bore well [2,3]. Chemical unique properties of water due to its polarization and hydrogen bonds which resources it is able to different combinations to suspended, dissolve, absorb in natural water, is unclear as it obtains pollutants from its nearby and individuals rising from people and animals as health as other biochemical actions [3]. The environmental contaminations by the toxic substances are growing that cause major concern to the local users. An extensive area of pollutants is constantly introduced into the aquatic environment primarily due to amplified industrial activity, technical development, growing human population and mistreatment of natural resources, agriculture and domestic wastes run-off. These pollutants, heavy metals found one of the most hazardous since of their stubborn nature, tendency, toxicity to accrue in organisms and undergo food chain increase and more still, they are non-degradable. Heavy metal causing major toxicity in humans like damage cardiovascular gastrointestinal track and CNS, the, endocrine glands, kidneys, liver, lungs, and bones. It is not probable to fully avoid contact to toxic metals. Even persons who are not occupationally uncovered transport some major metals in their human body as an outcome of exposure from other sources, such as food, beverages, or air. It is, though, probable to decrease metal toxicity risk concluded lifestyle se lections that contract the possibility of injurious heavy metal ap proval, such as alimentary procedures that may promote the safe metabolism or excretion of ingested heavy metals [4]. Humans have evolved in the presence of metals and are adapted to various levels of essential and non-essential metals. Metals from dietary intake and environmental exposure eventually reach their target organs (brain, liver and kidney). The fate of metal inside the body is determined by its ability to modify these systems. Excess metals in body are excreted through urine and faeces or accumulated in various tissues. At higher concentrations metals become toxic. The supreme significant environmental problems today are ground water pollution [5] and among the extensive variety of pollutants effecting water properties, heavy metals obtain specific concern seeing their tough toxicity even at small applications [6]. Heavy metal can origin major effects of health with diverse signs dependent on the nature and amount of the heavy metal consumed [7]. Domestic uses of groundwater are used for agriculture and industrial determination in many parts of the world. Human Activities like swage and waste water release huge number of pollutants into the water. In India surface water and ground water are used for the anthropogenic and agriculture and industrial purpose [8]. In now days the growing of many industrial development machinery, incising pollutions and water are used to improvement of the pressure upon together our water and land sources. Contamination difficulties contain sewerage leakage procedure and landfills leeching. Some 
seaside areas, thorough impelling of fresh bore well water has produced salt water to interrupt into fresh-water aquifers. The growth process of world contamination of water are biggest threats have become progressively apparent and have led to major environmental problems [9].

Sources of Contamination Heavy Metal in Groundwater

\section{Natural sources}

In nature are found the extreme stages of heavy metals can happen by physical condition are like withstanding of rocks, volcanic eruptions, leach out into rivers, lakes and groundwater due to stroke of water [10]. The Earth's layer, productions from volcanoes and vaporization. In natural water are found various heavy metals. Mining activity of the across of world the metal leads to direct and indirect waste into the water [11].

\section{Anthropogenic sources}

Minor quantities of heavy metals are released while mining and wild producing of bulky amounts of metal, ores in open fires. With the industrial uprising, metals were mined from natural sources and treated in the industries from where heavy metals conceded on into the water. Likewise traces of heavy metals get into the environment over release of waste - both domestic, agricultural and from auto drains. Following list displays the several human activities done which heavy metals get into the water \& environment.

a) Smelting or treating of ores of metals.

b) Mining.

c) Burning of fossil fuels petroleum products.

d) Discharging industrial waste.

e) Discarding domestic waste.

f) Discarding from auto exhausts.

g) Using pesticides having salts of heavy metals [12].

\section{Mining activities}

Heavy metals are found in the earth's physical background and consequently come in water sources concluded natural procedures. Example of the contamination of mining activity through heavy rains or fluid water can leaching heavy metals out of physical background. Such procedures are improved when this physical property is disturbance by commercial actions such as mining. These procedures representation the mined waste telling area to water can lead to significances such as acid mine drainage [13].

\section{Mineral extraction}

Mineral dispensation processes can also produce major heavy metal contamination, both from through removal procedures (which naturally involve size decrease - significantly accumulative the external mass area transferal - and produce wastes over leach out from ore and tailings accumulations [13].

\section{Electronic waste}

Electronic properties Industrial Corporations essential be legitimately guaranteed to indication the discarding procedures of their product in their user guide book. Recognized major toxicity producing by E-wastes and main source of heavy metals, dangerous compounds and carcinogens, diseases connected to intestinal, immune, skin, respiratory, and endocrine CNS and cancers containing can be prohibited by appropriate management and removal of E-waste. With an estimation to association the digital distribute, there is exponential growing in the use of Electrical and electronic apparatus and so around is troubling effect on people and environment when the ICT wastes are not discard of systematically [14].

\section{Heavy Metals in Water \& Effect on Human Health \\ Arsenic (As)}

Arsenic toxicity also presents a syndrome, which is associated to, and frequently disorganized with Guillain-Barre disease, an anti-immune illness that occurs when the bodies resistant function incorrectly occurrences part of the PNS, resultant in nerve irritation that reasons muscle weakness. Arsenic is the most significant heavy metals affecting concern from both environmental and separate health stand points. The metallic function of arsenic and is apparently toxic and carcinogenic, and is generally obtainable in the form of oxides or sulfides or as a salt of iron, sodium, calcium, copper, etc. Arsenic are 20th most abundant metals are originating in earth its arsenic on geological and its mineral systems such as arsenate and arsenite multiplexes are fatal to the atmosphere and current people. sulfhydryl group of cells producing malfunctioning of cell breathing, mitosis and cell enzymes mostly effected by Arsenic [13]. People health outcome toxicity of arsenic happens due to consumption of as consuming dusts or solutions by mistake, homicide, suicide, or ingestion of contaminated food or drinking water. Arsenic was caused to relate to hypertension and major impacts on the cardiovascular structure, and even hepatic damaging in the extreme quantity taken $[15,16]$. An exploitive result release on spermatogenesis and gonadotrophin and testosterone in human [17].

\section{Lead (Pb)}

Lead is a hazardous component; it is injurious even in minor quantities. Lead component comes in the Human body majorly found in water and food. It can be gasped in powder form of lead in paints, or excess gases from leaded petroleum products. It is originated in minor quantities in several water bodies \& food, particularly fish, which remain seriously focus to industrialized toxic waste. Approximately old households might water pipes consume lead, which can then pollute intake water. Contact to lead is growing above period. Extreme level of lead absorptions in the human body can cause death or perpetual harm to the brain, central nervous system and kidneys [18]. The devices fundamental lead developed neurotoxicity is compound. Anxiety, membrane bio-physics modifications or cell motioning deregulation and the damage of neurotransmission are important char- 
acteristics difficult in lead neurotoxicity. It can cause toxicity by oxidative anxiety straight or ultimately by lipid peroxidation resultant in the group of sensitive oxygen types (ROS), counting hydroperoxides, singlet oxygen, hydrogen peroxide and through reduction of antioxidant investments. Lead reduces enzymes nonfunctional by compulsory to their sulfhydryl group's additional contribution to a damage in oxidative balance [19]. The capability of lead to permit above the barrier blood and brain is mostly due to its capability to extra for calcium ions. Major toxicity of lead causing the brain prefrontal hippocampus, cerebellum and cerebral cortex can lead to a variability of neurological disorder, such as brain injury, psychological delay, behavior difficulties, nerve injury, and probably Alzheimer's disease, Parkinson's disease and schizophrenia [20].

\section{Nickle (Ni)}

Nickel is usually found in human tissues and, under situations of high exposure, these levels may rise significantly $[21,22]$. In the universal population, contributions to the people intake of nickel in the air and from drinking water are normally less significant than dietary intake and absorption is the most significant way of exposure. The consumption of nickel is dependent on its physicochemical procedure, with water-soluble methods (chloride, nitrate, sulphate) presence further readily consumption. In animals, $1-10 \%$ of the dietary nickel is consumption by the route of gastrointestinal. It is significant to note that the means in which nickel is absorbed may importantly affect its bioavailability $[23,24]$. While differences in distribution happen as a role of way of exposure, the solubility of the nickel element and period after exposure, the major target organs for nickel-induced general toxicity are the lungs and the higher respiratory tract for inhalation exposure and the kidney for oral exposure. Additional object organs contain the cardiovascular system, the immune system and blood [25,26]. Human exposure to extremely nickel-polluted in water has the probable to produce a range of pathological affects. Amongst them are skin allergies, lung fibrosis, cancer of the respiratory tract and iatrogenic nickel toxicity [27-29]. A various research studies are shown that established the hepatic toxicity related with nickel exposure and dose-related modifications in serum enzyme action were observed following animal treatment with nickel. Nephrotoxicity has been noted and aminoaciduria and proteinuria were the directories of nickel toxicity. Nickel exposure has been conveyed to produce hematological effects in both humans and animals. Although no reproductive effects have been linked with nickel exposure to humans $[25,29,30]$.

\section{Chromium (Cr)}

Chromium is a naturally arising metal existing on the geological, by states corrosion ranging from chromium [31]. Chromium arrives into several environmental mediums (water, soil and air) from an extensive variability of anthropogenic and natural sources with the major discharge upcoming from industry establishing. Industry with the major involvement to discharge chromium contain metal dispensation, tannery services, chromate manufacture, welding stainless steel, and ferrochrome and chrome pigment manufacture. The growth in the environment contamination of chromium has remained associated to wastewater and air discharge of chromium, mostly from metallurgical, and biochemical productions. Contaminated chromium into the environment from major anthropogenic action happens generally in the hexavalent method. Hexavalent chromium is a poisonous industry waste contaminant that is categorized as human carcinogen by numerous controlling and non- controlling activities $[32,33]$.

Environmental exposure of chromium is involving mixtures compound is known to produce multi organ poisonousness such as asthma, allergy, renal damage and major effect cancer of the respirational tract in people [34,35]. Inhalation extreme level of chromium can origin frustration to the covering of the nose and ulcers. The major health difficulties seen in human subsequent consumption of chromium mixtures are impatience and ulcers in the small intestine and abdominal, anemia, damage male reproductive system and sperm damage. Chromium mixtures are plentiful fewer poisonous and do not perform to origin these difficulties. Nearly persons are tremendously sensitive to chromium, allergic responses containing of severe swelling and redness of the skin have remained noted. A growth in abdominal tumors was observed in people and animals showing to chromium in water. The consumption of excessive quantity was taken of chromium complexes by humans takes resulted in plain respiratory, cardiovascular, gastrointestinal, hematological, hepatic, renal, and neurological effects as part of the sequelae important to death or in patients who persisted as per medical treatment. Though the indication of carcinogenicity of chromium in people and global living thing appears tough [36].

\section{Zinc (Zn)}

Zinc is an important mineral apparent by the human today as being excellent biologic and human health significance, mainly concerning prenatal and perinatal growth. Zinc deficiency effects around two billion public in the rising global and is related with several illnesses. In children its sources development delay, late sexual development, infection vulnerability, and diarrhea. Enzymes with a zinc particle in the sensitive focus are extensive in chemistry, such as liquor dehydrogenase in people Zinc insufficiency is generally due to unsatisfactory dietary consumption, but can be correlated with malabsorption, Acrodermatitis enteropathica, liver damage, renal damage, sickle cell damage, diabetes, malignancy, and other chronic diseases assemblies at hazard for zinc deficiency contain the elderly, children in rising nations, and individuals with renal deficiency. Signs of mild zinc insufficiency are varied. Medical consequences contain depressed development, diarrhea, weakness and late sexual development, alopecia, eye and skin abrasions, decreased appetite, changed perception, decreased host protection possessions, defects in carbohydrate utilization, and reproductive spermatogenesis [37]. 


\section{Discussion}

This review study shows that $\mathrm{Zn}, \mathrm{Ni}, \mathrm{Cr}$, As and $\mathrm{Pb}$ levels in all the groundwater high but above the permissible limits as recommended by WHO \& USEPA its causing toxicity to human. The toxicologist has constantly noticed the heavy metal concentration in several groundwater, plants, herbs, soil, etc. directly affected by human health is the drinking of polluted groundwater. People should be beware of the hazardous effects of drinking polluted water. It is suggested that consciousness must be spread between the people about the toxic on consumption of polluted groundwater and contaminated eatables. It is also important that agriculturalists must be educated to decrease such pollution and should be encouraged to use the controlled quantity of pesticides, to avoid the leaching of waste water. Cultivation of fields should be practiced far away from industrial region as well as areas disposed to pollution. Technologies are suggested for field cultivation and commercialization in the growing countries also where cultivation, urbanization, E-waste and industrialization are leaving a legacy on environmental degradation of Heavy metals.

\section{Conclusion}

Currently the India is leading toward development. Development for an India is mainly defined by its Industries \& Mines. Variety of trace elements, some of them are potentially toxic and are transferred to the surrounding groundwater through different pathways. Groundwater come to be polluted by the major heavy metals through discharges from the quickly increasing industrial regions, mine tailings, discarding of metal wastes, leaded gasoline and paints, etc. A major requirement to conserve controller on discarding of polluted industrial water sources and to anthropogenic pollution of the heavy metal in the groundwater. It is suggested that awareness should be extent among the people concerning the toxicity of drinking groundwater contaminated.

\section{References}

1. Vanloon GW, Duffy SJ (2005) The Hydrosphere. In: Environmental Chemistry: A Global Perspective. (2 ${ }^{\text {nd }}$ edn), Oxford University Press, New York, USA, pp: 197-211.

2. McMurry J, Fay RC (2004) Hydrogen, Oxygen and Water. In: McMurry Fay Chemistry, Hamann KP (Ed.). (4 ${ }^{\text {th }}$ edn), New Jersey: Pearson Education, pp: 575-599.

3. Mendie U (2005) The Nature of Water. In: The Theory and Practice of Clean Water Production for Domestic and Industrial Use. Lacto-Medals Publishers, Lagos, pp: 1-21.

4. Kumar R, Tripathi RM, Gupta AK (2014) Seasonal Variation of heavy metal concentration in water of River Yamuna, Allahabad, Uttar Pradesh, India. Int J Curr Microbiol App Sci 3(7): 945-949.

5. Vodela JK, Renden, Lenz SD, Mchel Henney WH, Kemppainen BW (2001) Drinking water contaminants. Poult Sci 76: 1474-1492.

6. Marcovecchio JE, Botte SE, Freije RH (2007) Heavy Metals, Major Metals, Trace Elements. In: Nollet LM (Ed.), Handbook of Water Analysis. ( $2^{\text {nd }}$ edn), CRC Press, London, pp: 275-311.

7. Adepoju-Bello AA, Alabi OM (2005) Heavy metals: A review. The Nig J Pharm 37: 41-45.
8. Kamble PN, Gaikwad VB, Kuchekarl SR (2011) Monitoring of Physico Chemical Parameters and Quality Assessment of Water from Bhandaradara Reservoir. Der Chemica Sinica 2(4): 229-234.

9. Shah DG, Patel PS (2011) Physico-chemical characteristics of bore wells drinking water of Kathalal territory district-Kheda, Gujarat. Der Chemica Sinica 2(5): 8-11.

10. Bagul VR, Shinde DN, Chavan RP, Patil CL, Pawar RK (2015) New perspective on heavy metal pollution of water. J Chem Pharma Res 7(12): 700-705.

11. Liu H, Li L, Yin C, Shan B (2008) Fraction distribution and risk assessment of heavy metals in sediments of Moshui Lake. Journal of Environmental Sciences 20(4): 390-397.

12. Armah FA, Quansah R, Luginaah I (2014) Int Scholarly Res Notices, pp. 1-37.

13. Sankhla MS, Kumari M, Nandan M, Kumar R, Agrawal P (2016) Heavy metals contamination in water and their hazardous effect on human health: a review. Int J Curr Microbiol Appl Sci 5(10): 759-766.

14. Sankhla MS, Kumari M, Nandan M, Mohril S, Singh GP, et al. (2016) Effect of Electronic waste on Environmental \& Human health- A Review. IOSR J Environmental Science Toxicology Food Technology (IOSR-JESTFT) 10(9): 98-104.

15. Lee MY, Jung BI, Chung SM, Bae ON, Lee JY, (2003) Arsenic-induced dysfunction in relaxation of blood vessels. Environ Health Perspect 111(4): 513-517.

16. Yoshida T, Yamauchi H, Fan Sun G (2004) Chronic health effects in people exposed to arsenic via the drinking water: dose-response relationships in review. Toxicol Appl Pharmacol 198(3): 243-252.

17. Sarkar M, Chaudhuri GR, Chattopadhyay A, Biswas NM (2003) Effect of sodium arsenite on spermatogenesis, plasma gonadotrophins and testosterone in rats. Asian J Androl 5(1): 27-31.

18. USGAO (2000) Health Effect of lead in drinking water. U.S. General Accounting Office reports.

19. Khan DA, Qayyum S, Saleem S, Khan FA (2008) Lead-induced oxidative stress adversely affects health of the occupational workers. ToxicolInd Health 24(9): 611-618.

20. Sanders T, Liu Y, Buchner V, Tchounwou PB (2009) Neurotoxic effects and biomarkers of lead exposure: a review. Rev Environ Health 24(1): 15-45.

21. Grandjean P (1984) Human exposure to nickel. IARC Sci Publ 53: 469485.

22. Chang LW (1996) Toxicology of Metals. Lewis Publishers: New York, USA, pp. 245-246.

23. Barceloux DG (1999) Nickel. J Toxicol Clin Toxicol 37(2): 239-258.

24. Haber LT, Erdreicht L, Diamond GL, Maier AM, Ratney R, et al. (2000) Hazard identification and dose response of inhaled nickel-soluble salts. Regul Toxicol Pharmacol 31(2 Pt 1): 210-230.

25. Coogan TP, Latta DM, Snow ET, Costa M (1989) Toxicity and carcinogenicity of nickel compounds. Crit Rev Toxicol 19(4): 341-384.

26. Nielsen GD, Søderberg U, Jørgensen PJ, Templeton DM, Rasmussen SN et al. (1999) Absorption and retention of nickel from drinking water in relation to food intake and nickel sensitivity. Toxicol Appl Pharmacol 154(1): 67-75.

27. Clarkso NTW (1988) Biological Monitoring of Toxic Metals; Plenum Press: New York, USA, pp. 265-282.

28. Kasprzak KS, Sunderman FW, Salnikow K (2003) Nickel carcinogenesis. Mutat Res 533(1-2): 67-97.

29. IRIS (1996) Nickel, soluble salts. 
30. Donskoy E, Donskoy M, Forouhar F, Gillies CG, Marzouk A, et al. (1986) Hepatic toxicity of nickel chloride in rats. Ann Clin Lab Sci 16(2): 108117.

31. Jacobs JA, Testa SM (2005) Overview of chromium (VI) in the environment: background and history. In: Guertin J, Jacobs JA, Avakian CP (Eds.), Chromium (VI) Handbook. Boca Raton, Fl: CRC Press, USA pp. 1-22.

32. IARC (1990) IARC Monographs on the Evaluation of Carcinogenic Risks to Humans. IARC, Chromium, nickel and welding. Vol. 49. Lyon, IARC Scientific Publications, France.

33. U.S, EPA, Environmental Criteria and Assessment Office. Cincinnati, OH: United States Environmental Protection Agency; 1992. Integrated Risk Information System (IRIS)
34. Goyer RA (2001) Toxic effects of metals. In: Klaassen CD (Ed.), Cassarett and Doull's Toxicology: The Basic Science of Poisons. McGraw-Hill Publisher, New York, USA, pp. 811-867.

35. WHO/IPCS, World Health Organization (1988) Environmental Health Criteria 61: Chromium, Geneva, Switzerland.

36. Chen TL, Wise SS, Kraus S, Shaffiey F, Levine K, et al. (2009) Particulate hexavalent chromium is cytotoxic and genotoxic to the North Atlantic right whale (Eubalaena glacialis) lung and skin fibroblasts. Environ Mol Mutagenesis 50(5): 387-393.

37. Dutta D, Sarma HP (2015) Copper (Cu), Zinc (Zn) and Cadmium (Cd) Contamination of Groundwater in Dikrong River Basin, Paumpare District, Arunachal Pradesh, India.

This work is licensed under Creative

Commons Attribution 4.0 License

DOI: 10.19080/IJESNR.2019.18.555996
Your next submission with Juniper Publishers will reach you the below assets

- Quality Editorial service

- Swift Peer Review

- Reprints availability

- E-prints Service

- Manuscript Podcast for convenient understanding

- Global attainment for your research

- Manuscript accessibility in different formats ( Pdf, E-pub, Full Text, Audio)

- Unceasing customer service

Track the below URL for one-step submission https://juniperpublishers.com/online-submission.php 